\title{
Paired Box Gene 8 (Pax8) Is also an Immunomarker of B-Cell Lineage Which Can Be Source of Diagnostic Pitfalls
}

\author{
Paolo Gasparri and Luca Roncati* \\ Department of Medical and Surgical Sciences, University Hospital of Modena, Modena, Italy
}

Paired box 8 (PAX8) is a transcription factor, which in humans is encoded by the PAX8 gene, located on the chromosome 2 , cytoband q14.1. ${ }^{1}$ It belongs to the paired box protein family, consisting of nine members from PAX1 to PAX9. ${ }^{1}$ This family of transcription factors is so called because all the members share the same $\mathrm{N}$-terminal paired box domain composed of about 120 amino acids. The PAX proteins are further subdivided into four groups on the basis of the presence (or absence) in their molecular structure of an octopeptide and of a paired-type homeobox at the C-terminal domain: PAX8 is placed in the second group together with PAX5 and PAX2. ${ }^{2}$

PAX8 is a master regulator in thyroid development; moreover, it plays an important role in the organogenesis of the thymus, kidneys, Müllerian system, eyes, and brain. $^{3-7}$

Several immunohistochemical studies have demonstrated the importance of PAX8 as immunomarker for different epithelial neoplasms arising in the thyroid and parathyroid gland, thymus, female and male genital tract or kidneys, including the Wilms' tumor. ${ }^{8-13}$

Some authors have also reported PAX8 expression in pancreatic islet cells and in neuroendocrine tumors of the pancreas, as well as in carcinoids arising in the duodenum, rectum and stomach. ${ }^{14,15}$

Consequently, the pathologists exploit PAX8 immunostaining to differentiate primary and metastatic PAX8positive tumors from PAX8-negative ones. ${ }^{9,12}$

As mentioned above, PAX5 is inserted in the same group as PAX8, however, unlike PAX8, PAX5 is encoded by a gene
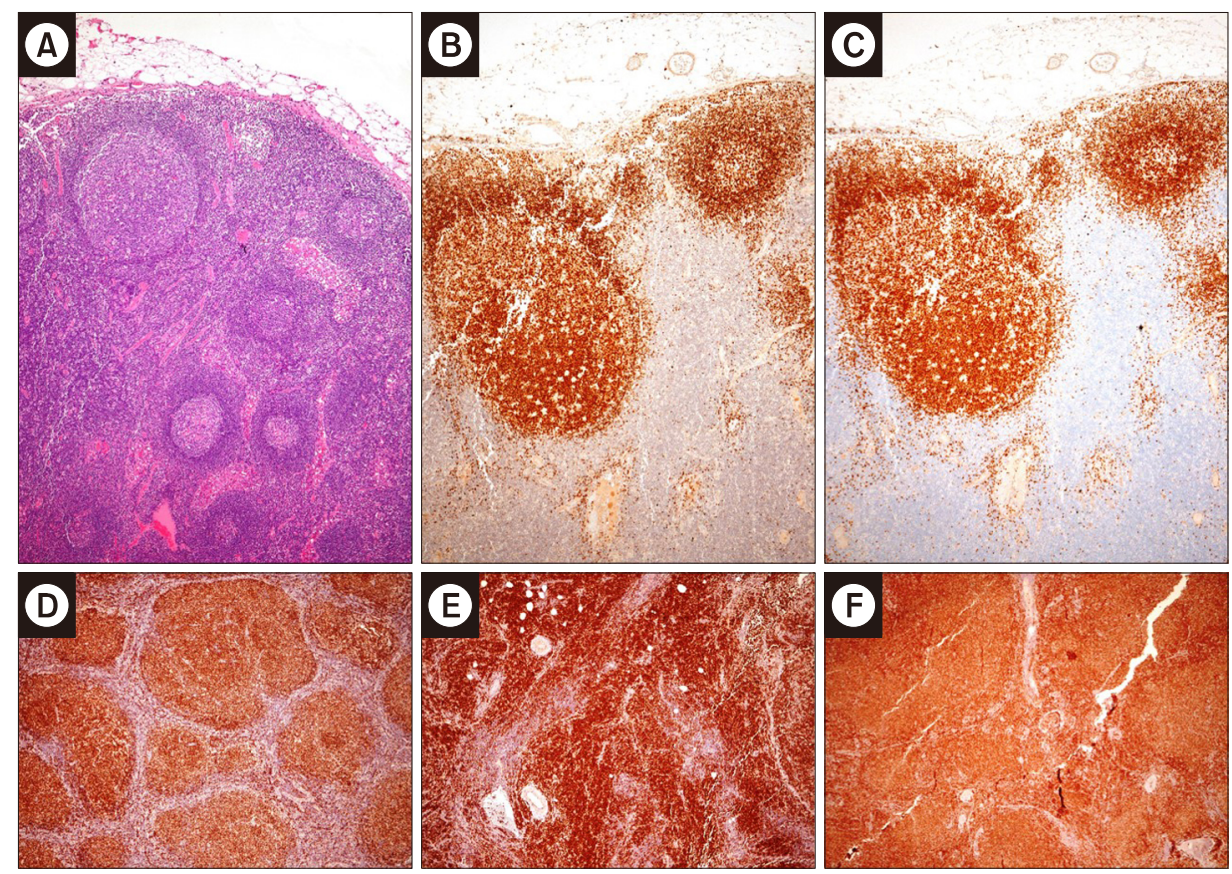

FIG. 1. Reactive lymphadenitis (A, hematoxylin \& eosin; $4 \times$ ): the germinal centers, the mantles and the marginal zone are brown-stained by immunohistochemistry for PAX8 (B, clone MRQ-50, Ventana; 5x) and PAX5 (C, clone SP34, Ventana; $5 \times$ ) in an overlapping manner involving the B-cell nuclei. Germinal center-derived lymphoma (D, $4 \times$ ), mantle cell lymphoma (E, $4 \times)$ and marginal zone lymphoma (F, $4 \times$ ) are strongly labeled by PAX8 immunohistochemistry [chromogen: 3,3' diaminobenzidine tetrahydrochloride hydrate].

\footnotetext{
Corresponding Author:

Luca Roncati

Department of Medical and Surgical Sciences, Institute of Pathology, University Hospital of Modena, Policlinico, I-41124 Modena, Italy

Tel: +390594224812, Fax: +390594224998, E-mail: emailmedical@gmail.com
}

Article History:

Received September 25, 2018 Accepted October 15, 2018 
located on chromosome 9 , cytoband p13.2, and it plays a significant role in early B-cell differentiation as well as in neural development and spermatogenesis. ${ }^{3,16,17}$

PAX5 immunostaining is used by pathologists in the diagnosis of most B-cell non-Hodgkin lymphomas/leukemias, Hodgkin lymphomas, where it faintly depicts ReedSternberg and Hodgkin cells, and in the differential diagnosis between plasmacytoma (PAX5-negative) and lymphoplasmacytic lymphoma/marginal zone lymphoma with plasmacytoid differentiation (PAX5-positive). ${ }^{16-19}$

As it is well known, a secondary follicle, which arises from a primary follicle after an antigenic stimulation of $B$ cells, is provided with a germinal center and a mantle zone. Externally to the mantle zone there is the marginal zone, which is difficult to distinguish, except when it is expanded, as in the course of benignant or lymphomatous proliferations. $^{20-23}$

Literature has reported that PAX8 stains B lymphocytes and B-cell lymphomas. ${ }^{24-26}$ To prove the validity of this statement, we have at first immunohistochemically evaluated the PAX5 and PAX8 expression in 50 consecutive normal lymph nodes removed for staging purposes in as many patients affected by epithelial malignancies. In all the tested cases, PAX8 was labeled at the germinal center, the mantle, and the marginal zone, exactly as PAX5 (Fig. 1). Subsequently, we have enrolled 25 cases of germinal center-derived lymphomas, 25 cases of mantle cell lymphoma and 25 cases of marginal zone lymphomas, coming from patients of any age, gender, or ethnicity, all resulted immunohistochemically positive for PAX5 and PAX8, as deriving from mature B cells (Fig. 1).

Since PAX8 is not involved in the process of B-lymphocyte commitment maintaining the same immunohistochemical profile of PAX5, many authors have wondered if that of PAX8 was a real positive. For example, Moretti and colleagues have tested PAX8 and PAX5 in reactive lymph nodes, in diffuse large B-cell lymphomas, and in Hodgkin lymphomas using for PAX5 a monoclonal antibody, and for PAX8 both a N-terminal polyclonal antibody (pPAX8), and a C-terminal monoclonal antibody (mPAX8). ${ }^{27}$ The results were the same for PPAX8 and PAX5, that were both positive in all lymphomas and reactive lymph nodes, while mPAX8 was negative in all the tested cases. ${ }^{27}$ In a similar manner, Morgan et al. ${ }^{28}$ investigated pPAX8, mPAX8 and PAX5 in a cohort of B-cell lymphomas, obtaining the same expression profile for pPAX8 and PAX5. In conclusion, we can state that PAX8 and PAX5 immunohistochemistry are overlapping in the routine diagnostic practice and, therefore, PAX8 positivity in lymphomas should not be surprising. On the other hand, this evidence should be kept in mind by the pathologists in order to avoid diagnostic pitfalls and mistakes.

\section{CONFLICT OF INTEREST STATEMENT}

None declared.

\section{REFERENCES}

1. Mansouri A, Hallonet M, Gruss P. Pax genes and their roles in cell differentiation and development. Curr Opin Cell Biol 1996;8: 851-7.

2. Treisman J, Harris E, Desplan C. The paired box encodes a second DNA-binding domain in the paired homeo domain protein. Genes Dev 1991;5:594-604.

3. Chi N, Epstein JA. Getting your Pax straight: Pax proteins in development and disease. Trends Genet 2002;18:41-7.

4. Dehbi M, Pelletier J. PAX8-mediated activation of the wt1 tumor suppressor gene. EMBO J 1996;15:4297-306.

5. Poleev A, Fickenscher H, Mundlos S, Winterpacht A, Zabel B, Fidler A, et al. PAX8, a human paired box gene: isolation and expression in developing thyroid, kidney and Wilms' tumors. Development 1992;116:611-23.

6. Mansouri A, Chowdhury K, Gruss P. Follicular cells of the thyroid gland require Pax8 gene function. Nat Genet 1998;19:87-90.

7. Bouchard M, Souabni A, Mandler M, Neubüser A, Busslinger M. Nephric lineage specification by Pax2 and Pax8. Genes Dev 2002; 16:2958-70.

8. Nonaka D, Tang Y, Chiriboga L, Rivera M, Ghossein R. Diagnostic utility of thyroid transcription factors Pax8 and TTF-2 (FoxE1) in thyroid epithelial neoplasms. Mod Pathol 2008;21:192-200.

9. Laury AR, Perets R, Piao H, Krane JF, Barletta JA, French C, et al. A comprehensive analysis of PAX8 expression in human epithelial tumors. Am J Surg Pathol 2011;35:816-26.

10. Tacha D, Zhou D, Cheng L. Expression of PAX8 in normal and neoplastic tissues: a comprehensive immunohistochemical study. Appl Immunohistochem Mol Morphol 2011;19:293-9.

11. Bowen NJ, Logani S, Dickerson EB, Kapa LB, Akhtar M, Benigno $\mathrm{BB}$, et al. Emerging roles for PAX8 in ovarian cancer and endosalpingeal development. Gynecol Oncol 2007;104:331-7.

12. Ozcan A, Shen SS, Hamilton C, Anjana K, Coffey D, Krishnan B, et al. PAX 8 expression in non-neoplastic tissues, primary tumors, and metastatic tumors: a comprehensive immunohistochemical study. Mod Pathol 2011;24:751-64.

13. Ozcan A, Liles N, Coffey D, Shen SS, Truong LD. PAX2 and PAX8 expression in primary and metastatic müllerian epithelial tumors: a comprehensive comparison. Am J Surg Pathol 2011;35: 1837-47.

14. Long KB, Srivastava A, Hirsch MS, Hornick JL. PAX8 expression in well-differentiated pancreatic endocrine tumors: correlation with clinicopathologic features and comparison with gastrointestinal and pulmonary carcinoid tumors. Am J Surg Pathol 2010;34:723-9.

15. Sangoi AR, Ohgami RS, Pai RK, Beck AH, McKenney JK, Pai RK. PAX8 expression reliably distinguishes pancreatic well-differentiated neuroendocrine tumors from ileal and pulmonary well-differentiated neuroendocrine tumors and pancreatic acinar cell carcinoma. Mod Pathol 2011;24:412-24.

16. Adams B, Dörfler P, Aguzzi A, Kozmik Z, Urbánek P, MaurerFogy I, et al. Pax-5 encodes the transcription factor BSAP and is expressed in B lymphocytes, the developing CNS, and adult testis. Genes Dev 1992;6:1589-607.

17. Torlakovic E, Torlakovic G, Nguyen PL, Brunning RD, Delabie J. The value of anti-pax-5 immunostaining in routinely fixed and 
paraffin-embedded sections: a novel pan pre-B and B-cell marker. Am J Surg Pathol 2002;26:1343-50.

18. Desouki MM, Post GR, Cherry D, Lazarchick J. PAX-5: a valuable immunohistochemical marker in the differential diagnosis of lymphoid neoplasms. Clin Med Res 2010;8:84-8.

19. Feldman AL, Law ME, Inwards DJ, Dogan A, McClure RF, Macon WR. PAX5-positive T-cell anaplastic large cell lymphomas associated with extra copies of the PAX5 gene locus. Mod Pathol 2010; 23:593-602.

20. Roncati L, Maiorana A. Ectopic extra-nodal in situ follicular neoplasia (ISFN). J Hematopathol 2016;9:151-3.

21. Roncati L, Maiorana A. IgA plasmablastic large B-cell lymphoma. Diagnosis (Berl) 2017;4:105-7.

22. Roncati L. De novo CD5-positive primary gastric diffuse large B-cell lymphoma coexpressing MYC and BCL6: towards a proper subset of double-hit, triple-hit and, maybe, quadruple-hit B-cell lymphomas? Chonnam Med J 2018;54:80-2.

23. Roncati L, Barbolini G, Piacentini F, Piscioli F, Pusiol T, Maiorana A. Prognostic factors for breast cancer: an immunomorphological update. Pathol Oncol Res 2016;22:449-52.

24. Parakh R, Cheng L, Tretiakova M. PAX8-positive B-cell lymphoma in adrenal gland masquerading as metastatic renal cell carcinoma. Int J Surg Pathol 2018;26:721-4.

25. Hirsch MS, Nascimento AF. PAX8 distinguishes diffuse large B-cell lymphoma mimicking sarcoma. Case Rep Pathol 2017; 2017:6714549.

26. Hubbard EW, Nodit L, Van Meter S. Undifferentiated malignant neoplasm involving parotid and thyroid: sampling and PAX8 cross-reactivity can obscure the diagnosis of lymphoma. Case Rep Pathol 2016;2016:3291549.

27. Moretti L, Medeiros LJ, Kunkalla K, Williams MD, Singh RR, Vega F. N-terminal PAX8 polyclonal antibody shows cross-reactivity with $\mathrm{N}$-terminal region of PAX5 and is responsible for reports of PAX8 positivity in malignant lymphomas. Mod Pathol 2012;25:231-6.

28. Morgan EA, Pozdnyakova O, Nascimento AF, Hirsch MS. PAX8 and PAX5 are differentially expressed in B-cell and T-cell lymphomas. Histopathology 2013;62:406-13. 